\title{
Studies on the Binding of Aldosterone in the Toad Bladder*
}

\author{
Geoffrey W. G. Sharp, † Constance L. Komack, and Alexander Leaf
}

(From the Departments of Medicine, Harvard Medical School and the Massachusetts General Hospital, Boston, Mass.)

The stimulation of sodium transport in the toad bladder by aldosterone is well established (1-3), and the toad bladder serves as a useful model for the study of mineralocorticoid activity. Sodium transport is stimulated by physiological concentrations of aldosterone and by other steroids with mineralocorticoid activity, but inhibited by spirolactones, progesterone, and ouabain (4). Evidence has been obtained for the involvement of protein synthesis in the mechanism of action (5-7), and the dependence on aerobic metabolic pathways has been demonstrated $(8-11)$. The present study is an attempt to examine the binding of aldosterone in this tissue, which should provide information on the site and nature of the receptors, on the reason for a delay in the onset of action of aldosterone, and on the mode of action of aldosterone antagonists.

The present study is based on the assumption that the hormone must bind or associate with responsive receptor sites in the tissue in order to elicit its specific effect. The problem is to distinguish the hormone present in this functional capacity from that which will unavoidably accumulate within the tissue because of favorable solubility or adsorption properties of the tissue.

As an approach to this problem a technique has been used that should distinguish bound or adsorbed hormone in the tissue from that which is not bound. When hormone is added to isolated tissue that can neither synthesize nor destroy it, the hormone will distribute itself so that it attains

* Submitted for publication June 21, 1965 ; accepted December 9, 1965.

This investigation was supported in part by grants from the John A. Hartford Foundation, Inc., and by U. S. Public Health Service research grants HE-06664 from the National Heart Institute and AM-04501 from the National Institute of Arthritis and Metabolic Diseases.

† Address requests for reprints to Dr. G. W. G. Sharp, Massachusetts General Hospital, Boston, Mass. 02114. equal chemical potential in all portions of the tissue that it can penetrate. Its concentration in different portions of the tissue or within individual cells may vary greatly, however, because of partitioning resulting from differences in solubility or adsorption. At the low concentrations in which hormonal effects may be elicited, one would not anticipate saturation of solubility; however, one would expect that adsorbed or bound hormone molecules may be displaced or exchanged with free molecules. By first exposing tissue to low concentrations of radioactively labeled hormone, binding or adsorption sites will be occupied by hormone of high specific activity. Subsequent addition of nonlabeled hormone to the tissue at higher concentrations will displace labeled molecules from reversible binding sites without affecting the distribution of the unbound hormone. The loss of radioactivity from the tissue upon exposure to the displacing concentration of nonradioactive hormone is thus a measure of the bound hormone in the tissue.

This technique should distinguish bound from unbound hormone in the tissue, but it will not, of course, indicate the physiologically significant from the nonspecifically bound or adsorbed hormone. The present study attempts to establish a physiological role for one portion of the bound hormone.

\section{Methods}

1) The determination of the total $d$-aldosterone- ${ }^{3} \mathrm{H}$ in the tissue. The determination of the rate of uptake of $d$-aldosterone- ${ }^{8} \mathrm{H}$ was carried out by incubating tissue from toad bladders in Ringer's solution containing known concentrations of $d$-aldosterone- ${ }^{3} \mathrm{H}$ for periods of up to 120 minutes. The Ringer's solution contained $\mathrm{Na}^{+}, 113.5$; $\mathrm{K}^{+}, 3.5 ; \mathrm{Cl}^{-}, 116.5 ; \mathrm{HCO}_{3}^{-}, 2.4 \mathrm{mEq}$ per $\mathrm{L}$; and $\mathrm{Ca}, 0.89$ mmole per $\mathrm{L}$; the total solute concentration was 220 mOsm per $\mathrm{kg}$ and the $\mathrm{pH}$ in air, 7.8 to 8.1. At the end of each incubation period, the tissues were removed, and the radioactivity in the tissues was determined by the following procedure: The tissue was drained of excess 
fluid, rinsed in Ringer's solution, blotted quickly with Whatman 54 filter paper to remove surface moisture, and weighed on a torsion balance. The tissues were then placed directly into polyethylene counting vials containing $200 \mu 1$ of $1 \mathrm{M}$ sodium hydroxide solution and the vials placed in a warm water bath until the tissues dissolved. To each vial $15 \mathrm{ml}$ scintillation fluid was added. Samples of the incubation medium, each of $250 \mu \mathrm{l}$, were also mixed with $15 \mathrm{ml}$ scintillation fluid in separate vials. The scintillation fluid had the following composition (12): p-bis-[2-(5-phenyloxazoly1)]-benzene (POPOP), $0.13 \mathrm{~g}$; 2,5-diphenyloxazole (PPO), $6.5 \mathrm{~g}$; naphthalene, $104 \mathrm{~g}$; methyl alcohol, $300 \mathrm{ml}$; dioxane, $500 \mathrm{ml}$; and toluene, $500 \mathrm{ml}$. Kandel and Gornall (13) have warned of the dangers inherent in counting low concentrations of $d$-aldosterone- ${ }^{8} \mathrm{II}$ due to variable adsorption of the hormone on the sides of the vial. For this reason 2 to $4 \%$ Cab-osil ${ }^{1}$ was included in the scintillation mixture. Aldosterone is adsorbed to the Cab-o-sil and the counting efficiency uniformly reduced by half, but the variability is eliminated.

The radioactivity in the tissues and medium was determined with a liquid scintillation spectrometer. ${ }^{2}$ To correct the quenching effect of the tissues, we added a known and constant amount of $d$-aldosterone- ${ }^{3} \mathrm{H}$ to the tissue vials and blanks after the initial count and recounted the whole. Quenching of the internal standard was then calculated for each tissue and the appropriate correction applied. The magnitude of quenching was estimated in 114 determinations and found to average some $10 \%$. All the toads used in this study were maintained for at least 48 hours in saline solutions of approximately $0.6 \%$ before use and rapidly pithed to minimize endogenous production of aldosterone. Bladders were promptly removed after pithing.

2) The determination of the amount of bound d-aldosterone ${ }^{-3} H$ in the tissue. The procedure outlined above determines the total amount of $d$-aldosterone- ${ }^{8} \mathrm{H}$ in the tissue. The amount bound within the tissues was determined as follows: Bladders were divided into eight pieces of approximately equal weight and placed in separate flasks containing a known concentration of $d$-aldosterone${ }^{8} \mathrm{H}$ in 3 to $5 \mathrm{ml}$ of Ringer's solution and incubated with agitation for 60 minutes at $25^{\circ} \mathrm{C}$. At 60 minutes a 1,000 fold excess of $d$-aldosterone (over $d$-aldosterone- ${ }^{3} \mathrm{H}$ ) was added to four of the eight flasks in order to displace labeled hormone from the tissue. Incubation was continued for a further 60 minutes. The $d$-aldosterone was dissolved in $5 \mu \mathrm{l}$ of methyl alcohol. An equal amount of methyl alcohol was added to the remaining four flasks. At the end of the second 60 minutes of incubation, the tissues were removed and treated as in section 1 for the determination of radioactivity in the tissue. The amount of $d$-aldosterone- ${ }^{8} \mathrm{H}$ displaced from the tissue is calculated from the difference in radioactivity in the tissues incubated with $d$-aldosterone- ${ }^{8} \mathrm{H}$ alone, and that of the paired tissues which in addition had been exposed to an excess of unlabeled $d$-aldosterone. The amount displaced is

1 Cabot. Corp., Boston, Mass.

2 Packard Instrument Co., La Grange, Ill. assumed to equal the amount that had been bound to sites in the tissues.

3) The determination of the displacenent of aldosterone by other compounds. The ability of other steroids and compounds of interest to displace aldosterone was determined as outlined above in section 2, except that deoxycorticosterone, cortisol, a spirolactone (SC 14266), ${ }^{3}$ progestcrone, ouabain, cholesterol, puromycin, and actinomycin $\mathrm{D}$ were each used in place of the excess $d$-aldosterone for the 60 -minute displacement period.

The displacement of aldosterone by different concentrations of displacing agents was performed as outlined in section 2, except that four different concentrations of each compound studied were added to the flasks for displacement of the $d$-aldosterone- ${ }^{3} \mathrm{H}$. Concentrationdisplacement relationships for aldosterone, deoxycorticosterone, cortisol, and SC 14266 were obtained.

4) The determination of the rate of displacement of aldosterone. The determination of the rate of displacement of aldosterone from the binding sites was performed as outlined in section 2, except that displacement by excess of $d$-aldosterone was carried out for various periods of time from 15 to 60 minutes. Pairs of tissues were removed at the end of each displacement period so that a time course was obtained from each toad bladder.

5) The determination of rates of elution of aldosterone. Toad bladders were divided into eight pieces and incubated in $10 \mathrm{ml}$ of Ringer's solution containing either $10^{-\theta} \mathrm{M}$ or $10^{-10} \mathrm{M} d$-aldosterone- ${ }^{-3} \mathrm{H}$. After 90 minutes the tissues were removed, drained of excess fluid, rinsed briefly, and placed in individual flasks containing $10 \mathrm{ml}$ of Ringer's solution. The amount of radioactivity in the tissues was determined, as before, at elution times ranging from 0 to 240 minutes after removal from the radioactive solution. The incubation and elution were carried out with agitation at $25^{\circ} \mathrm{C}$.

$d$-Aldosterone- ${ }^{-8} \mathrm{H}$ was obtained commercially. ${ }^{4}$ Both initially, and after a 3-hour period of incubation with the toad bladder, an average of $96 \%$ of the tritium radioactivity was associated with $d$-aldosterone. ${ }^{5}$ The accuracy of this assay method, which utilizes chromatographic migration with $d$-aldosterone $-4{ }^{14} \mathrm{C}$, is $\pm 5 \%$.

6) The determination of sodium transport. The effects on sodium transport of exposing toad bladder to aldosterone for only 5 minutes were studied by the shortcircuit technique with double chambers. This apparatus differs from the conventional chamber described by Ussing and Zerahn (14) in that two chambers are placed side by side. In this way one half bladder may be mounted across the two chambers, one quarter serving as the test preparation and the other as the control. Each compartment of the double chamber was filled with $15 \mathrm{ml}$ Ringer's solution. When the spontaneous transbladder potential is reduced to zero, the electrical current flowing in the external circuit is equal to the sodium transport across the bladder. $d$-Aldosterone in solu-

${ }^{3}$ G. D. Searle, Chicago, IIl.

4 New England Nuclear Corp., Boston, Mass.

${ }^{5}$ Determined by Dr. B. Kliman using his own assay method. 
TABLE I

Rate of uptake of d-aldosterone by toad bladder

\begin{tabular}{|c|c|c|c|c|c|}
\hline \multirow{2}{*}{$\begin{array}{c}\text { Concentration of } \\
d \text {-aldosterone }\end{array}$} & \multirow{2}{*}{$\begin{array}{l}\text { No. of } \\
\text { experiments }\end{array}$} & \multicolumn{4}{|c|}{ Amount in tissue $\times 10^{-11} \pm \mathrm{SEM}$} \\
\hline & & $30 \mathrm{~min}$ & $60 \mathrm{~min}$ & $90 \mathrm{~min}$ & $120 \mathrm{~min}$ \\
\hline mole/L & \multicolumn{5}{|c|}{ mole/g } \\
\hline $1 \times 10^{-7}$ & 10 & $16.6 \pm 1.2$ & $18.0 \pm 0.6$ & $17.3 \pm 0.9$ & $17.7 \pm 1.4$ \\
\hline
\end{tabular}

tion in methanol was added to the medium bathing the serosal surface of the test quarter bladder to a final concentration of $9 \times 10^{-7}$ mole per $L$. An equal volume of methanol, $5 \mu \mathrm{l}$, was added to the control. After $5 \mathrm{~min}$ utes the aldosterone was removed by draining the chambers and refilling them with $20 \mathrm{ml}$ of fresh Ringer's solution. This procedure was carried out three times; the chambers were refilled finally with $15 \mathrm{ml}$ Ringer's solution. The short-circuiting and measurements were performed automatically.

\section{Results}

The uptake of aldosterone by the tissue. Table I shows the time course of the uptake of total aldosterone in the tissue. By 30 minutes the tissue uptake was $94 \%$ of the mean of the subsequent three values and not significantly different from them. Thus, uptake by the tissue is rapid and essentially complete by 30 minutes.

The binding of aldosterone by the tissue. The total concentration of hormone in the tissue relative to that in the medium varies in a manner characteristic of adsorption or binding; the lower the concentration of aldosterone in the medium, the greater, is the relative concentration in the tissue. The amount of aldosterone displaced from the tissue after incubation with four different concentrations of $d$-aldosterone- ${ }^{8} \mathrm{H}$ is shown in Figure 1. At $10^{-7} \mathrm{M}$ aldosterone in the medium the concentration in whole tissue was 1.7 -fold that in the medium, whereas at $10^{-10} \mathrm{M}$ medium concentrations the ratio was 2.9 , as seen in Table II.

Table II also indicates that the per cent of the aldosterone in the tissue that was bound varied from 19 to 32 at medium concentrations of $10^{-2}$ and $10^{-10}$ mole per $\mathrm{L}$, respectively. By subtracting the bound hormone from the total hormone in the tissue and dividing the difference by the concentration of the hormone in the medium, one obtains the coefficient for the accumulation of aldosterone in the tissue relative to the medium. This value is shown in the last column of Table II. However, the concentration of aldosterone used to displace the hormone bound in the tissue was 1,000-fold greater than the concentrations of hormone in the medium indicated in the first column of Table II. Thus the distribution coefficients represent concentrations in the medium from $10^{-7}$ to $10^{-4}$ mole per $\mathrm{L}$. It can be seen that the distribution coefficient is essentially a constant over the range of concentrations of aldosterone in the medium from $10^{-7}$ to $10^{-5}$ mole per L. At $10^{-4}$ mole per $\mathrm{L}$, however, the distribution coefficient decreases significantly, suggesting either that the solubility of the aldosterone in some portion of the tissue phase had been exceeded at these high concentrations in the medium or that a third binding site of very low affinity was saturated. The constancy of the

TABLE, II

The amount of d-aldosterone present, and the amount of d-aldosterone bound, in toad bladder tissue

\begin{tabular}{|c|c|c|c|c|}
\hline $\begin{array}{l}\text { Concentration } \\
\text { of } d \text {-aldos- } \\
\text { terone in } \\
\text { medium }\end{array}$ & $\begin{array}{c}\text { No. of } \\
\text { experiments }\end{array}$ & $\begin{array}{l}\text { Amount of } d \text {-aldosterone } \\
\text { present in tissue } \pm S E M\end{array}$ & $\begin{array}{l}\text { Amount of } d \text {-aldosterone } \\
\text { bound in tissue } \pm S E M\end{array}$ & $\begin{array}{l}\text { Distribution } \\
\text { coefficient } \\
\pm \text { SEM }\end{array}$ \\
\hline mole /I. & & mole/g & mole/g & \\
\hline $\begin{array}{l}10^{-7} \\
10^{-8} \\
10^{-9} \\
10^{-10}\end{array}$ & $\begin{array}{l}7 \\
7 \\
7 \\
7\end{array}$ & $\begin{array}{l}16.7 \pm 0.9 \times 10^{-11} \\
24.1 \pm 2.3 \times 10^{-12} \\
27.5 \pm 1.0 \times 10^{-13} \\
29.4 \pm 2.4 \times 10^{-14}\end{array}$ & $\begin{array}{r}* 3.2 \pm 0.4 \times 10^{-11} \\
4.7 \pm 1.2 \times 10^{-12} \\
9.2 \pm 0.6 \times 10^{-13} \\
9.4 \pm 1.5 \times 10^{-14}\end{array}$ & $\begin{array}{l}1.35 \pm 0.07 \\
1.94 \pm 0.13 \\
1.83 \pm 0.06 \\
2.00 \pm 0.14\end{array}$ \\
\hline
\end{tabular}

* At $10^{\sim 7}$ mole per $L$ the quantity of hormone apparently bound in the tissue exceeds by some 20 -fold the total number of sites in the large set of binding sites. However, since at this concentration with the addition of the displacing concentration, the distribution coefficient falls significantly, the limits of solubility of aldosterone in the tissue must have been exceeded and some of the freely dissolved hormone displaced. 


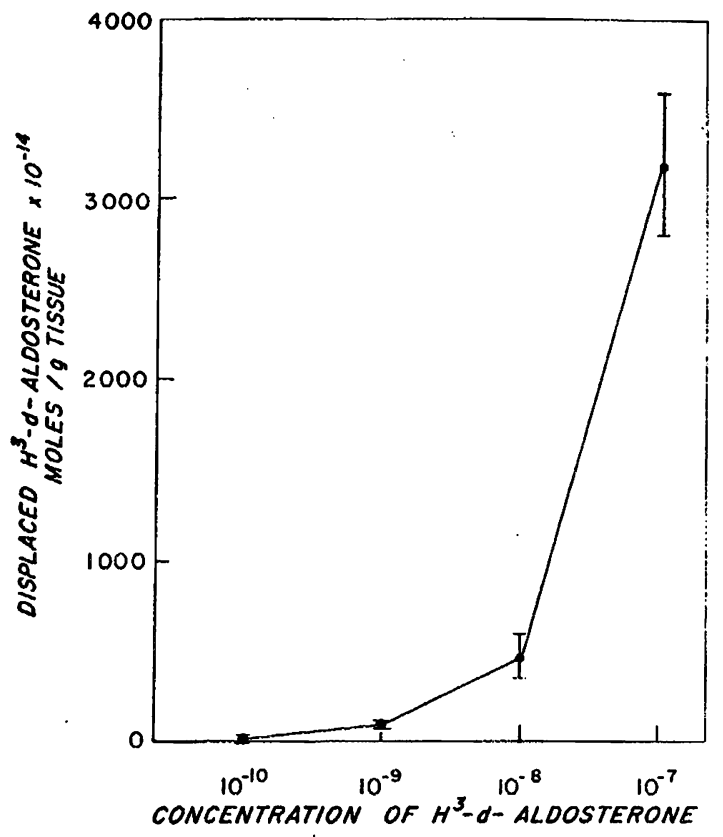

Fig. 1. The displacement OF D-ALDOSTERONE-'H from TOAD BLADDER BY EXCESS D-ALDOSTERONE. The abscissa is the concentration of $d$-aldosterone- ${ }^{3} \mathrm{H}$ in mole per liter to which the tissue was exposed initially for a period of 60 minutes. A 1,000-fold excess of nonradioactive $d$-aldosterone was then added to the medium to displace bound hormone from the tissue, and the amount of $d$-aldosterone ${ }^{8} \mathrm{H}$ so displaced is shown on the ordinate. The vertical bars at each point indicate standard error of the mean; $n=7$.

distribution coefficient up to medium concentrations tenfold greater than any used in the subsequent portions of this study justifies the initial assumption that the total hormone in the tissue is accounted for by one fraction that is bound but displaceable and another that obeys the distribution law. (15) for the partition of a solute between immiscible phases.

To study the nature of the association between aldosterone and the binding sites, we studied their affinity and heterogeneity. The application of a Scatchard plot to this problem enables one to determine the affinity and size of any group of sites $(16,17)$. The binding sites of highest affinity for aldosterone are most easily detected at low concentrations of the hormone. The lowest range of concentrations possible experimentally, and this is limited by the strength of the binding, bladder size, specific activity of the $d$-aldosterone- ${ }^{3} \mathrm{H}_{\text {; }}$ and the counting efficiency, was from $2.3 \times 10^{-11}$ to
$1 \times 10^{-9}$ mole per $L$. The results are shown in Figure 2.

The slope of the curve represents the affinity of the sites for aldosterone, whereas the intercept on the abscissa indicates the maximal number of sites having the observed affinity. Two sets of sites differentiated by their affinities were found. The sites with the higher affinity for aldosterone were detected at concentrations of $d$-aldosterone${ }^{3} \mathrm{H}$ less than $10^{-10}$ mole per $\mathrm{L}$. The small set of sites with the higher affinity binds a maximum of $9 \times 10^{-14}$ mole of aldosterone per $\mathrm{g}$ of tissue, whereas the sites of lower affinity bind a maximum of $3 \times 10^{-12}$ mole of aldosterone per $g$ of tissue.

The association constants for these two sets of sites and the percentage of the sites saturated at different concentrations of $d$-aldosterone- ${ }^{-8} \mathrm{H}$ are presented in Table III. It has been shown that the range of concentrations at which the tissue responds to aldosterone is from approximately $3 \times 10^{-10}$ to $1 \times 10^{-7}$ mole per $L$ (3). This range of concentration for physiological response

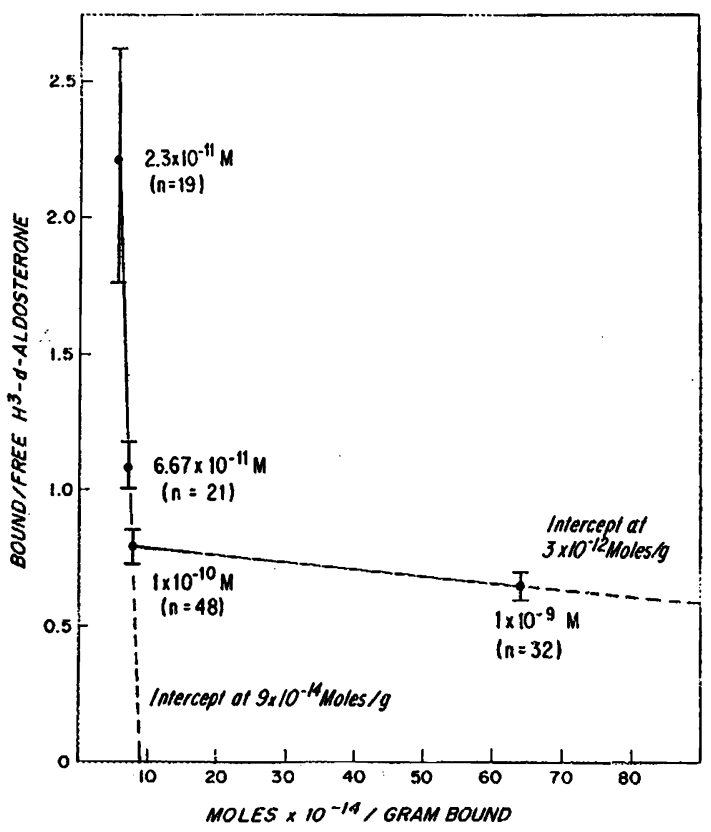

Fig. 2. A Scatchard plot of the binding of D-ALDOSTERONE- ${ }^{-} \mathrm{H}$ TO TOAD BLADDER. This representation reveals two sets of binding sites. The intercepts with the abscissa indicate the maximal number of binding sites, $9 \times 10^{-14}$ and $3 \times 10^{-12}$ mole per $g$ of tissue for the two sets. The affinity of each set is indicated by the slope of the line and is $1.4 \times 10^{14}$ and $4 \times 10^{25}$, respectively. 
TABLE III

The per cent saturation of binding sites at different concentrations of d-aldosterone in the medium

\begin{tabular}{ccc}
\hline $\begin{array}{c}\text { Concentration of } \\
d \text {-aldosterone }\end{array}$ & $\begin{array}{c}\text { Small set of sites } \\
\text { Kameocistion }=1.4 \times 10^{14}\end{array}$ & $\begin{array}{c}\text { Large set of sites } \\
\text { Kanooiaction }=4 \times 10^{12}\end{array}$ \\
\hline mole/L & $\%$ & $\%$ \\
$10^{-6}$ & & 99 \\
$10^{\cdots 7}$ & & 97 \\
$10^{-8}$ & 99 & 70 \\
$10^{-9}$ & 88 & 20 \\
$10^{-10}$ & & 2 \\
\hline
\end{tabular}

of the tissue to the hormone corresponds well with the percentage of binding in the large site. The small set would have achieved virtually complete saturation at concentrations of hormone in the medium too low to elicit a response. In the subsequent studies, however, parallel experiments were performed to examine the physiological role of each set, $10^{-10} \mathrm{M}$ hormone in the medium to study the small set and $10^{-0} \mathrm{M}$ hormone for the large set.

The displacement of aldosterone by other compounds. As the first test of the physiological role of the respective sets of binding sites, displacement of $d$-aldosterone by other compounds was examined. We had expected that mineralocorticoids other than aldosterone and structural competitive antagonists of aldosterone would displace $d$-aldos-

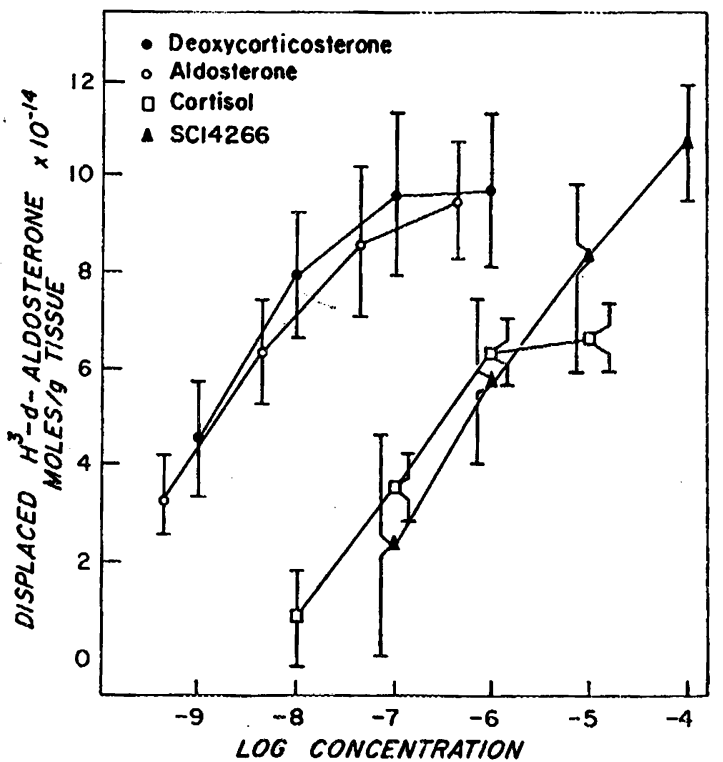

Fig. 3. ThE, DisplaCEMENT OF D-ALDOSTERONE- ${ }^{\circ} \mathrm{H}$ FROM TISSUE EXPOSED TO A CONCENTRATION OF $10^{-10} \mathrm{M}$ D-ALDOSTERONE-- ${ }^{8} \mathrm{H}$. BY DIFFERENT CONCENTRATIONS OF ADRENAL. STEROIDS AND A SPIROLACTONE.

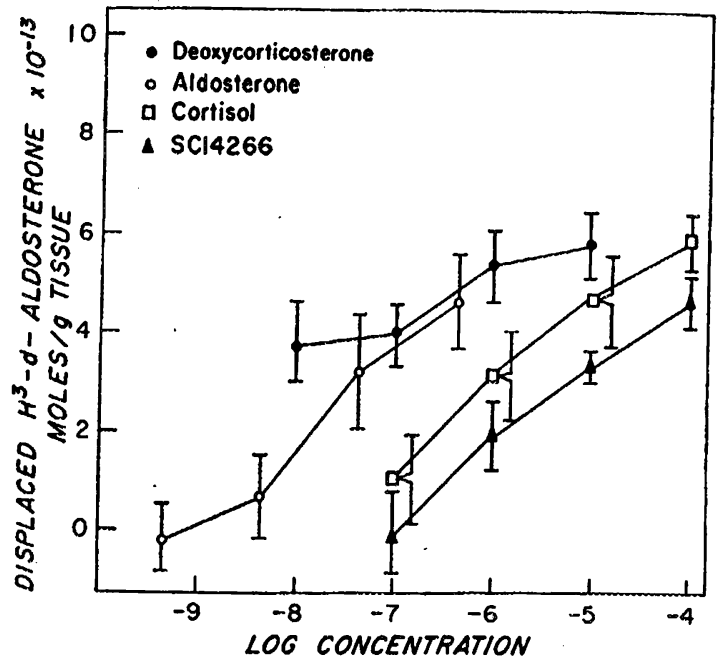

Fig. 4. THE Displacement OF D-ALDOSTERONE- ${ }^{3} \mathrm{H}$ FROM TISSUE EXPOSED TO A CONCENTRATION OF $10^{-0} \mathrm{M}$ D-ALDOSTERONE- ${ }^{3} \mathrm{H}$ BY DIFFERENT CONCENTRATIONS OF ADRENAL STEROINS AND A SPIROLACTONE.

terone $-{ }^{3} \mathrm{H}$ from active sites, whereas inactive steroids would not. Therefore, the displacing ability of several steroids was investigated by substituting them for $d$-aldosterone in the displacement procedure. Aldosterone, deoxycorticosterone, cortisol, and spirolactone (SC 14266) displace aldosterone from both sets of sites, and their displacing ability is of the order to be predicted from their activity in the tissue $(2,3)$. This is documented in that the slopes of the log concentration-response relationships shown in Figures 3 and 4 for. the small and large sets, respectively, are essentially similar for all four compounds (the first point in the deoxycorticosterone displacement in Figure 4 is an exception to this generalization, and the highest concentration of deoxycorticosterone tested shows saturation as do the higher concentrations used to determine the dose response curves for the high affinity set of sites shown in Figure 3 ). This indicates that the $d$-aldosterone- ${ }^{8} \mathrm{H}$ displaced in each case is derived from the same binding sites. Table IV shows that progesterone also displaced aldosterone from both sets of sites, whereas cholesterol did not. Figure 5 indicates that the displacing ability of progesterone is approximately one-tenth that of aldosterone.

Studies with three other compounds capable of antagonizing the action of aldosterone failed to exhibit displacing ability. The antagonists tested were ouabain, which at approximately $1 \times 10^{-5}$ 
TABLE IV

The displacement of $d$-aldosterone- ${ }^{3} H$ by different agents

\begin{tabular}{|c|c|c|c|c|c|}
\hline \multirow[b]{2}{*}{ Displacing agent } & \multirow[b]{2}{*}{$\begin{array}{l}\text { Concentration of } \\
\text { displacing agent }\end{array}$} & \multicolumn{2}{|c|}{$10^{-0} \mathrm{M} d$-aldosterone-2H } & \multicolumn{2}{|c|}{$10^{-10} \mathrm{M} d$-aldosterone..3H } \\
\hline & & $\begin{array}{c}\text { No. of } \\
\text { experiments }\end{array}$ & $\begin{array}{l}\text { d-Aldosterone- } \\
\text { sH displaced } \\
\times 10^{-18} \pm \text { SEM }\end{array}$ & $\begin{array}{c}\text { No. of } \\
\text { experiments }\end{array}$ & $\begin{array}{l}\text { d-Aldosterone- } \\
\text { 2H displaced } \\
\times 10^{-14} \pm \mathrm{SEM}\end{array}$ \\
\hline \multirow{7}{*}{$\begin{array}{l}\text { Aldosterone } \\
\text { Progesterone } \\
\text { Progesterone } \\
\text { Cholesterol } \\
\text { Puromycin } \\
\text { Actinomycin } \\
\text { Ouabain }\end{array}$} & mole/L & & mole/g & & mole/g \\
\hline & $4.5 \times 10^{-7}$ & 10 & $4.6 \pm 1.0$ & 10 & $9.5 \pm 1.3$ \\
\hline & $5 \times 10^{-7}$ & & & 11 & $9.3 \pm 1.8$ \\
\hline & $\begin{array}{l}1 \times 10^{-6} \\
1 \times 10^{-5}\end{array}$ & $\begin{array}{l}12 \\
12\end{array}$ & $\begin{array}{l}4.5 \pm 0.8 \\
0.6 \pm 1.8\end{array}$ & 32 & $0.0 \pm 1.0$ \\
\hline & $9 \times 10^{-6}$ & 18 & $0.1 \pm 1.0$ & 18 & $0.0 \pm 1.0$ \\
\hline & $1 \times 10^{-6}$ & 16 & $0.8 \pm 1.0$ & 11 & $0.5 \pm 1.0$ \\
\hline & $1 \times 10^{-5}$ & 12 & $0.6 \pm 1.1$ & 12 & $0.7 \pm 1.1$ \\
\hline
\end{tabular}

mole per $\mathrm{L}$ selectively antagonizes the stimulation of sodium transport by aldosterone $(4,10)$, actinomycin $(5,6)$, and puromycin (6), which are presumed to act via inhibition of RNA and protein synthesis, respectively $(18,19)$. The results are shown in Table IV.

The rate of interaction of aldosterone with binding sites. Table I documents the rapid uptake of aldosterone by the tissue. By 30 minutes a steady state for the accumulation of hormone by the tissue had been achieved. The rate at which the hormone interacts with the binding sites was next examined by determining the rate of displacement of $d$-aldosterone- ${ }^{3} \mathrm{H}$ from the bladder after incubation of the tissue with $10^{-10} \mathrm{M}$ or $10^{-9} \mathrm{M} d$-aldosterone- ${ }^{3} \mathrm{H}$. After 1 hour of incubation with

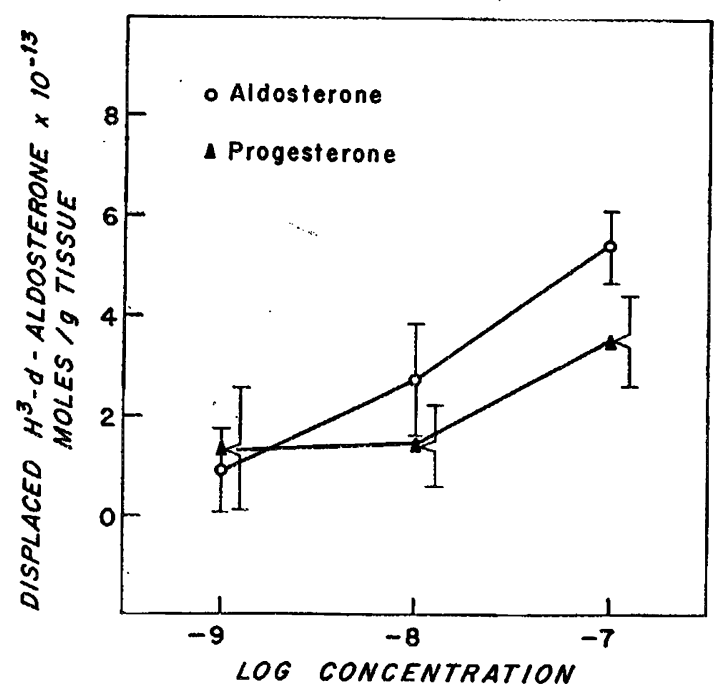

Fig. 5. The displacement OF D-ALDOSTERONE- ${ }^{8} \mathrm{H}$ FROM TISSUE EXPOSED TO A CONCENTRATION OF $10^{-\theta} \mathrm{M}$ D-ALDOSTERONE- ${ }^{8} \mathrm{H}$ BY DIFFERENT CONCENTRATIONS OF ALDOSTERONE AND PROGESTERONE. labeled aldosterone, a 1,000 -fold excess, $10^{-7}$ or $10^{-6}$ mole per $\mathrm{L}$, respectively, of $d$-aldosterone was added to the medium, and tissues were removed at $15,30,45$, and 60 minutes for determination of the amount of $d$-aldosterone- ${ }^{3} \mathrm{H}$ displaced by the nonlabeled hormone. The results shown in Figure 6 indicate that within 30 to 45 minutes the interaction of $d$-aldosterone with the binding sites is essentially complete for each concentration tested.

The elution of aldosterone. The elution of $d$-aldosterone from the toad bladder is illustrated in Figure 7. It can be seen that tissues incubated with either $10^{-9}$ or $10^{-10} \mathrm{M} d$-aldosterone- ${ }^{3} \mathrm{H}$ lose $70 \%$ of all the steroid in the tissue within $30 \mathrm{~min}$ utes when placed in plain Ringer's solution, and almost $90 \%$ in 90 minutes. This rate of elution from the tissue is of considerable interest in view of the fact that exposure of the toad bladder to aldosterone for only 5 minutes, followed by washing, elicits a stimulation of sodium transport after the usual lag phase. Figure 8 shows an actual

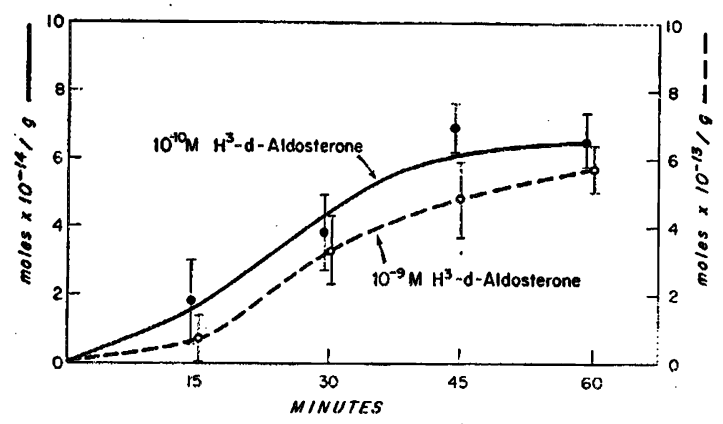

Fig. 6. The displacement of D-ALDOSTERONE- ${ }^{8} \mathrm{H}$ FroM TISSCE EXPOSED TO TWO DIFFERENT CONCENTRATIONS (10-10 OR $10^{-\theta} \mathrm{M}$ ) OF D-ALDOSTERONE- ${ }^{3} \mathrm{H}$ AS A FUNCTION OF TIME AFTER ADDITION OF A 1,000-FOLD EXCESS OF THE DISPLACING, NONRADIOACTIVE HORMONE TO THE MEDIUM. 

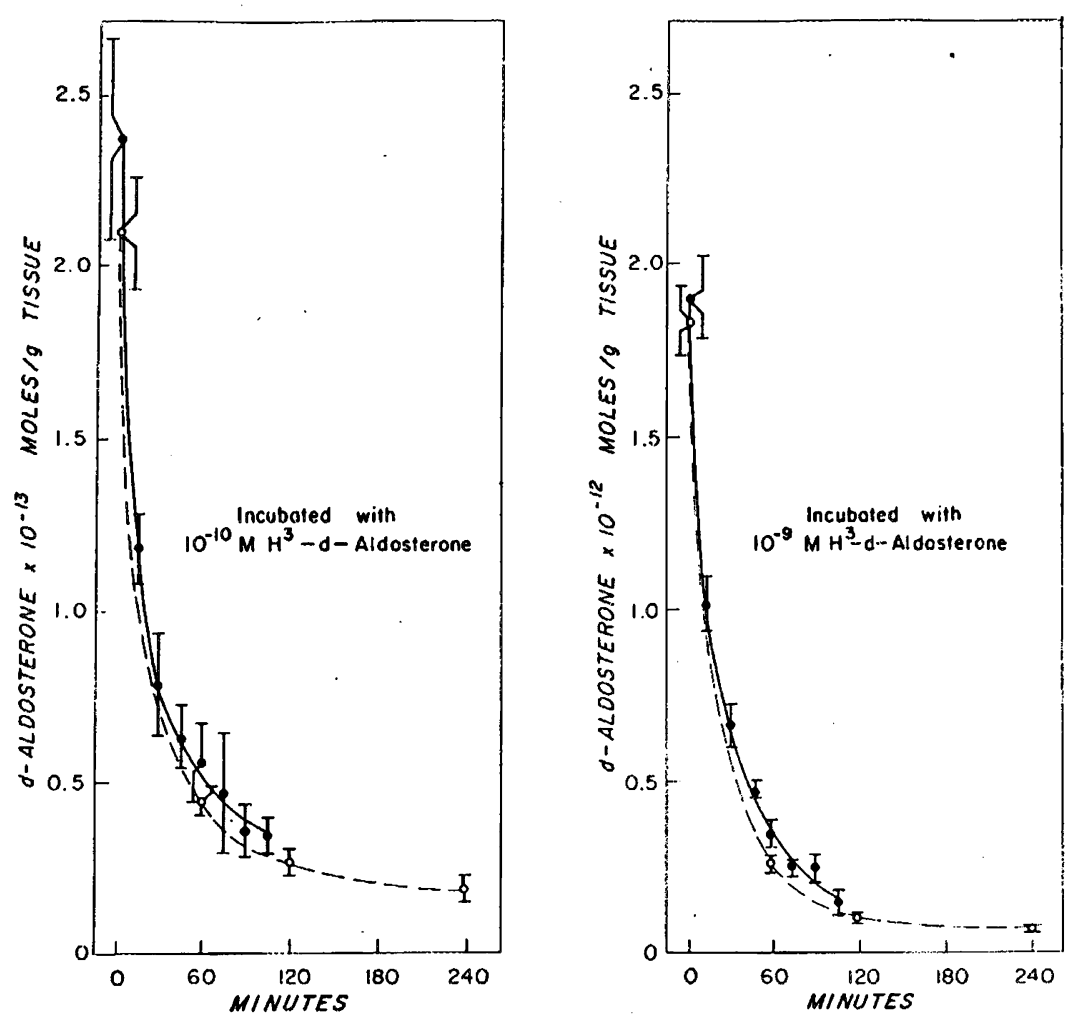

Fig. 7. The elution of D-Aldosterone from toad bladder. After incubation for 90 minutes with medium containing either $10^{-10}$ or $10^{-8} \mathrm{M} d$-aldosterone- ${ }^{3} \mathrm{H}$, the tissue was placed in medium without aldosterone, and the rate of decrease of activity in the tissue was determined. Two sets of experiments were done at each concentration of $d$-aldosterone- ${ }^{3} \mathrm{H}$ extending over different periods of time.

tracing of one of three similar experiments designed to illustrate this point. The sodium transport, measured as the short-circuit current, of two adjacent portions of a half bladder is shown. Five minutes after the addition of aldosterone to the serosal medium bathing one quarter bladder,

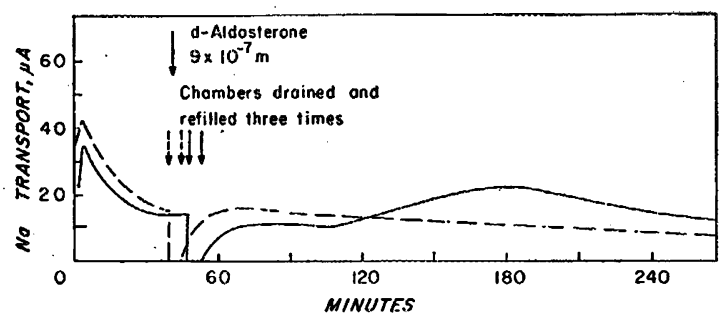

Fig. 8. THE EFFECT ON SODIUM TRANSPORT OF EXPOSING THE TOAD BLADDER TO ALDOSTERONE FOR ONLY 5 MINUTES. The characteristic stimulation of sodium transport is seen after a latent period of 1 hour in the portion of tissue that had been exposed to aldosterone for $5 \mathrm{~min}$ utes. The area of chamber from which each short-circuit current was measured was $2 \mathrm{~cm}^{2}$. the chamber was drained of Ringer's solution to remove the aldosterone and refilled with fresh Ringer's solution. The washing procedure was repeated twice more during the next five minutes and was applied to the control tissue as well as the tissue exposed to aldosterone. One hour after the removal of aldosterone from the chamber, stimulation of sodium transport commenced, reaching a maximum 2 hours after the washing procedure. No such stimulation occurred in the control tissue. It was estimated that after the washing procedure the concentration of residual hormone in the medium to which the tissue would still be exposed was less than $10^{-11}$ mole per $L$. Eight experiments were performed under conditions simulating the protocol of the experiment illustrated in Figure 7, and the tissue content of labeled aldosterone was measured at 120 and 180 minutes. The total content of $d$-aldosterone remaining was $13 \pm 3$ and $9 \pm 5 \times 10^{-13}$ mole per $g$, 
respectively. These small residua are equivalent to some 40 or $30 \%$, respectively, of the total number of binding sites in the large set. These results do not exclude the possibility that this small amount of aldosterone at the physiologic binding sites is responsible for the hormonal stimulation.

\section{Discussion}

This study represents an attempt to examine the physiologically meaningful interaction of aldosterone with a responsive tissue, the toad bladder. We anticipated that the hormone would accumulate within the tissue because of two different processes, preferential solubility of the hormone in some portions of the tissue and adsorption or binding of the hormone at other sites. We further anticipated that these two accumulatory processes might be differentiated by the displaceability of labeled hormone from sites of adsorption or binding but not from sites of preferential solubility. These expectations were confirmed by the following experimental findings: 1) The uptake by the tissue of labeled $d$-aldosterone from media of increasing concentration occurs in a manner characteristic of adsorption or binding. Thus the hormone was concentrated in the tissue relative to its concentration in the medium to a greater extent at low than at high concentrations of aldosterone in the medium. 2) A large excess of nonlabeled hormone does displace a portion of the $d$-aldosterone${ }^{3} \mathrm{H}$ that has accumulated in the tissue. 3) When the quantity of hormone in the tissue that is displaceable is subtracted from the total hormone accurnulated in the tissue, the difference divided by the concentration of hormone in the medium yields a constant value of 2.0 up to concentrations of aldosterone in the medium of $10^{-5}$ mole per $\mathrm{L}$. Such constancy is characteristic of the distribution law for the partition of a solute between two immiscible phases or is consistent with some very loose binding that showed no detectable saturation over the concentration range tested. Since the latter possibility seems unlikely, the total hormone accumulated by the tissue appears to be either in a free (soluble) state or as bound (adsorbed) hormone.

When the bound aldosterone was examined further, it was found to consist of two moieties. One portion was bound at exceedingly low concentrations with an association constant of $1.4 \times 10^{14}$ and a maximal number of binding sites of some $9 \times 10^{-14}$ mole of aldosterone per $\mathrm{g}$ of tissue. The other portion was bound with an association constant of $4 \times 10^{12}$ to a larger number of sites, $3 \times$ $10^{-12}$ mole per $g$ of tissue, assuming 1 molecule of aldosterone bound per site. The bound hormone was found to be readily displaceable from both sets of sites.

From the association constants the free energy, $\Delta G$, of binding may be estimated. Values of approximately 19 and $16 \mathrm{kcal}$ per mole for the small and large sets of binding sites, respectively, are obtained. From these values, however, one cannot directly deduce the nature of the binding, since the free energy of binding, $\Delta \mathrm{G}$, equals $\Delta \mathrm{H}-$ $\mathrm{T} \Delta \mathrm{S}$, in which $\Delta \mathrm{H}$ and $\Delta \mathrm{S}$ are the enthalpy and entropy changes of binding, respectively, and $T$ is the absolute temperature. Only $\Delta \mathrm{H}$ will provide information regarding the kind of bond between aldosterone and the receptor sites. $\Delta \mathrm{H}$ has not yet been determined. The magnitude of the values for the free energy of binding is not inconsistent with a rapid exchange of labeled and unlabeled molecules of aldosterone at the binding sites. One would not expect, however, rapid elution of the hormone from the binding sites. The rate of elution of the hormone from its binding sites, in contrast to the elution of the total hormone from the tissue, has not been determined for technical reasons.

The possible physiological significance of both sets of binding sites was examined in three ways: 1) by comparing the displacing ability of other steroids having mineralocorticoid activity with inactive steroids and steroids thought to act as structural competitive antagonists, 2) by determining the concentration-response (displacement) characteristics of selected steroids, and 3 ) by comparing the relative saturation of the two sets with the concentrations of aldosterone that elicit minimal to maximal stimulation of sodium transport in the toad bladder. Studies using a concentration of $10^{-10} \mathrm{M} d$-aldosterone- ${ }^{3} \mathrm{H}$ were used to determine the small set of sites and of $10^{-8} \mathrm{M} d$-aldosterone ${ }^{-3} \mathrm{H}$ to represent the larger set. It is clear that the hormone bound to both sites responds in accord with physiological expectation in that it can be displaced by other mineralocorticoids, by progesterone, and spirolactone, but not by cholesterol. Furthermore, the ability of these 
agents to displace $d$-aldosterone- ${ }^{3} \mathrm{H}$ is approximately proportional to their activity in the tissue, i.e., in the order of aldosterone and deoxycorticosterone, cortisol, and finally spirolactone $(2,3)$.

A distinct difference in the possible physiological significance of these two sets of bound hormone is evident, however, when the degree of saturation of their respective binding sites is examined as a function of the concentration of aldosterone in the medium. The small set shows virtually complete saturation at hormonal concentrations in the medium too low to elicit a detectable stimulation of sodium transport. The correspondence between the degree of saturation of the binding sites of the larger set and the range of concentrations of hormone to which the tissue responds physiologically, $3 \times 10^{-10}$ to $10^{-7}$ mole per $\mathrm{L}$, on the other hand, is excellent. From this we conclude that the larger set of sites $\left(\mathrm{K}_{\text {ussociation }}=4\right.$ $\times 10^{12}$ ) comprises the receptors most likely responsible for the stimulation of sodium transport by aldosterone. The function, if any, of the small set remains to be determined.

The hormone present in the tissue in a freely soluble form, as indicated by its adherence to the distribution law, has received no further considerations as being physiologically active for two reasons: 1) Our initial assumption was that the hormone would have to interact physically or chemically with some sites in the tissue in order to elicit an effect. 2) Spirolactone and progesterone, which block the physiological action of the hormone, displace aldosterone from its binding sites, but do not affect the aldosterone dissolved in the tissue. Therefore, the soluble hormone would not appear to be functionally active.

The fact that the total number of binding sites is $3 \times 10^{-12}$ mole per $\mathrm{g}$, whereas the amount of aldosterone in the tissue incubated at $10^{-7} \mathrm{M}$ hormone is $1.7 \times 10^{-10}$ mole per $\mathrm{g}$, indicates that only $2 \%$ of the hormone could have been bound. This makes localization of the physiologically active hormone within the whole tissue most difficult. Thus radioautographic localization of aldosterone, which does not distinguish bound from soluble hormone, cannot be expected to reveal the physiologically active binding sites in the tissue.

One theory of the mode of action of steroid hormones has been discussed by Willmer (20). According to this view the steroid hormone inter- digitates with lipids of the plasma membrane, altering thereby the permeability properties of the latter. A prompt response to the hormone would be expected from this mechanism of action, whereas the stimulation of sodium transport by aldosterone in the toad bladder occurs only after a latent period of approximately 1 hour. This study demonstrates that a significant amount of aldosterone is bound to its receptor sites by 30 minutes after exposure of the tissue to the hormone. The delay in the onset of the action of aldosterone cannot, therefore, result from the time required for the hormone to reach and bind with its receptors, but must represent time required for some process subsequent to the interaction of the hormone with its receptor.

Another argument against the hypothesis of hormonal action discussed by Willmer (20) comes from our observation (4) that stimulation of sodium transport could be detected after only brief contact of the tissue with the hormone. Thus, exposure of the tissue to the hormone for only $5 \mathrm{~min}$ utes was followed by stimulation of sodium transport 60 minutes later. We know from the present study that by the time the effect occurred the concentration of hormone in the tissue must have been low and falling. The stimulation of sodium transport after removal of aldosterone from the bathing medium has been confirmed by Edelman, Bogoroch, and Porter (6).

It is of interest that puromycin and actinomycin, which specifically antagonize the stimulation of sodium transport by aldosterone, presumably by inhibiting protein and RNA synthesis, respectively, fail to displace $d$-aldosterone ${ }^{3} \mathrm{H}$ from the tissue: Ouabain at a concentration of $10^{-5}$ mole per $\mathrm{I}$. $(4,10)$ also specifically antagonizes the stimulation of sodium transport by aldosterone, but likewise fails to displace $d$-aldosterone- ${ }^{3} \mathrm{H}$ from the tissue. This is consistent with the current hypothesis that ouabain inhibits a peripheral step in ion transport involving an adenosine triphosphatase $(21,22)$.

\section{Summary}

An attempt has been made to study the binding of aldosterone in a responsive tissue and to evaluate its physiological significance. The technique employed distinguished that hormone which was adsorbed or bound in the tissue from that in a free or soluble state. Physiological activity was associ- 
ated with only the former, which comprised only 33 to $2 \%$ of the hormone accumulated by the tissue when exposed to physiologically active concentrations of aldosterone, $3 \times 10^{-10}$ to $10^{-7}$ mole per $L$. The bound or adsorbed hormone was resolvable into two sets: one with high affinity, $\mathrm{K}_{\text {assoctation }}=1.4 \times 10^{14}$, and a maximal binding capacity of some $9 \times 10^{-14}$ mole of aldosterone per $\mathrm{g}$ of tissue, and another of lower affinity, $\mathrm{K}_{\mathrm{association}}$ $=4 \times 10^{12}$, binding $3 \times 10^{-12}$ mole of hormone per $\mathrm{g}$ of tissue. The bound hormone was displaced readily from both sets of sites by $d$-aldosterone, deoxycorticosterone, cortisol, progesterone, and spirolactone (SC 14266) but not by cholesterol. Because the binding sites of the large set were saturated at concentrations of hormone corresponding to maximal physiological activity, whereas those of the small set were essentially saturated at concentrations too low to elicit a physiological response, we concluded that the large set contains the receptors responsible for the hormonal effect. The characteristic latent period before onset of the hormonal effect is not attributable to a delay in the binding of the hormone with the tissue.

\section{Acknowledgments}

$d$-Aldosterone was generously provided by Dr. Maurice M. Pechet. The spirolactone (SC 14266) was a gift from G. D. Searle \& Co., Chicago, I11. Dr. B. Kliman's generosity in performing the assays on the purity of the $d$-aldosterone- ${ }^{-3} \mathrm{H}$ is gratefully acknowledged.

\section{References}

1. Crabbé, J. Stimulation of active sodium transport by the isolated toad bladder with aldosterone in vitro. J. clin. Invest. 1961, 40, 2103.

2. Porter, G. A., and I. S. Edelman. The action of aldosterone and related corticosteroids on sodium transport across the toad bladder. $J$. clin. Invest. 1964, 43, 611.

3. Sharp, G. W. G., and A. Leaf. Biological action of aldosterone in vitro. Nature (Lond.) 1964, 202, 1185.

4. Sharp, G. W. G., and A. Leaf. Studies on the biological action of aldosterone in vitro (abstract). J. clin. Invest. 1963, 42, 978.

5. Williamson, H. E. Mechanism of the antinatriuretic action of aldosterone. Biochem. Pharmacol. 1963, $12,1449$.

6. Edelman, I. S., R. Bogoroch, and G. A. Porter. On the mechanism of action of aldosterone on sodium transport: the role of protein synthesis. Proc. nat. Acad. Sci. (Wash.) 1963, 50, 1169.
7. Porter, G. A., R. Bogoroch, and I. S. Edelman. On the mechanism of action of aldosterone on sodium transport: the role of RNA synthesis. Proc. nat. Acad. Sci. (Wash.) 1964, 52, 1326.

8. Sharp, G. W. G., and A. Leaf. The central role of pyruvate in the stimulation of sodium transport by aldosterone. Proc. nat. Acad. Sci. (Wash.) 1964, 52, 1114.

9. Sharp, G. W. G., N. S. Lichtenstein, and A. Leaf. Acetyl coenzyme A requirement for the stimulation of sodium transport by aldosterone. Biochim. biophys. Acta (Amst.) 1965, 111, 329.

10. Sharp, G. W. G., and A. Leaf. Metabolic requirements for active sodium transport stimulated by aldosterone. J. biol. Chem. 1965, 240, 4816.

11. Fimognari, G., D. K. Kasbekar, and I. S. Edelman. Role of pyruvate metabolism in the action of aldosterone on $\mathrm{Na}^{+}$transport. Fed. Proc. 1965, 24, 344.

12. Frenkel, E. P., B. E. Whalley, C. T. Knorpp, and D. R. Korst. On the counting of tritiated thymidine in tissues. J. Lab. clin. Med. 1962, 59, 174.

13. Kandel, M., and A. G. Gornall. Effect of glass surfaces on the liquid scintillation counting of aldosterone. Canad. J. Biochem. 1964, 42, 1833.

14. Ussing, H. H., and K. Zerahn. Active transport of sodium as the source of electric current in the short-circuited isolated frog skin. Acta physiol. scand. 1951, 23, 110.

15. Glasstone, S. Textbook of Physical Chemistry. Princeton, N. J., D. van Nostrand, 1946, p. 735.

16. Scatchard, G. The attractions of proteins for small molecules and ions. Ann. N. Y. Acad. Sci. 1949, 51,660 .

17. Edsall, J. T., and J. Wyman. Biophysical Chemistry. New York, Academic Press, 1958, vol. 1, p. 617.

18. Reich, E., R. M. Franklin, A. J. Shatkin, and E. L. Tatum. Effect of actinomycin D on cellular nucleic acid synthesis and virus production. Science 1961, 134, 556.

19. Yarmolinsky, M. B., and G. L. de la Haba. Inhibition by puromycin of amino acid incorporation into protein. Proc. nat. Acad. Sci. (Wash.) 1959, 45, 1721.

20. Willmer, E. N. Steroids and cell surfaces. Biol. Rev. 1961, 36, 368.

21. Skou, J. C. The relationship of a $\left(\mathrm{Mg}^{++}+\mathrm{Na}^{+}\right)$activated, $\mathrm{K}^{+}$-stimulated enzyme or enzyme system to the active, linked transport of $\mathrm{Na}^{+}$and $\mathrm{K}^{+}$ across the cell membrane in Membrane Transport and Metabolism, A. Kleinzeller and A. Kotyk, Eds. Prague, Czechoslovak Academy of Sciences, 1961, p. 228.

22. Post, R. L., and C. D. Albright. Membrane adenosine triphosphatase system as a part of a system for active sodium and potassium transport in Membrane Transport and Metabolism, A. Kleinzeller and A. Kotyk, Eds. Prague, Czechoslovak Academy of Sciences, 1961, p. 219. 